\title{
Overcoming the Problem of Learning Foreign Language Skills in the Classroom
}

\author{
Sokip \\ Department of Arabic Education, Faculty of Education, State Islamic University, IAIN Tulungagung, East Java, Indonesia
}

Received October 20, 2019; Revised January 10, 2020; Accepted January 17, 2020

Copyright $\bigcirc 2020$ by authors, all rights reserved. Authors agree that this article remains permanently open access under the terms of the Creative Commons Attribution License 4.0 International License

\begin{abstract}
In the Education sector, there are several obstacles faced by non-native speaker students who learn a foreign language. Although, they currently have got their first language to help them learn a foreign language such as English and Arabic, while it does not rule out the possibility of acquiring a second language. Language learning is always driven by the language skills, in which each student must pass on four language skills that have different difficulties in each skill. In this case, it is very interesting to explore the problems and effective strategies used to help non-native speaker students overcome the existed language problems. This writing aims to find out the various problems faced by students in obtaining foreign languages such as English and Arabic and by knowing the existed problems the researcher also finds out the solution to at least reduce the problems. Hence, to answer the research objectives, the researcher used the Library research method. The findings revealed several problems within each language skill and found several solutions in the form of teaching strategies to reduce problems in language understanding in students.
\end{abstract}

Keywords Language Competence, Problem, Solution, Teaching Strategy

\section{Introduction}

Enhancing the competence of language skills cannot be separated from the aspects of education. The aspects are professional educator, teaching material, curriculum, teaching strategy, teaching media, infrastructure, and so on. For instance, in the level of elementary school, the students experience how they change their abilities, both achieving better or worst ones [1]. This case has commonly emerged in the Indonesian Educational system and process. Hence, to help students encounter their problems, the educational institution must always be aware of and improved based on students' circumstances and era development.

Speaking about language definitely holds an exciting term to be discussed. Moreover, the problems that occur in language learning on students considered as "non-native speakers". According to Izzan, the function of the second language is that language is used by people to express their feelings, emotions, hopes, desires, ideas, and thoughts. Conversely, language also displays a tool for understanding and living the feelings, hopes, desires, and thoughts of others [2]. Therefore, it can be said that the existence of language can be a necessary thing for every single human being to carry out interaction.

Meanwhile, learning the second language is not as easy as turning the palm of the hand. The studies of Al-khresheh [3-8] showed different problems that foreign and second language learners face. These problems fall into different linguistic categories and affect all language skills.

There are various challenges faced by users who considered "non-native speaker" students. Although they are currently have got their first language at home or Indonesian, however, it does not rule out that the possibility of acquiring a second language (English or Arabic) is much more challenging to learn. Other factors play a role also in case of understanding learning within each competency (language skills) which consists of four abilities. Furthermore, English in Indonesia is mostly taught in classroom learning. It also occurs globally in Jordanian schools that as a foreign language, English is taught in the field of the school, college, and higher education level [7]. As a result, English is only learned by students while they are entering their classroom, or shortly not much attention to practice English competency beyond the institution.

In general, all language learning experts agree that language skills are divided into four, namely listening skill, speaking skill, reading skill, and writing skill, [10]. 
These four skills are made into the foundation or basic to determine the type of learning strategy which is suitable and effective on language in use.

\section{Literature Review}

The term "problem" comes from English which means difficulty or obstacle. Meanwhile, in the Indonesian term, the word "problem" defines as something that cannot be overcome yet. While other experts say that problems mean a gap between expectations and reality that are expected to be able to resolve or in other words can reduce the gap [10]. So that in the context of learning problems can be described as problems when learning science. This is in accordance with the opinion of Dimyati and Sudjiono [11] that the problem of learning is the challenge that hinders learning.

According to Sumardi as cited in Syahputra [12] the learning process and teachers dominate in learning. The teacher gives more provisions in the form of theory and knowledge of a language than prioritizing language skills both oral and written. According to Thu'aimah, [13], the meaning in second language learning is caused by various factors. These factors can come from students, they are weak of hearing, weak of vision, weak of memories, impaired speech, mental disorders, less able to get along with friends, and some have certain individual or social problems. Moreover, lack of experience with second languages. Based on the several factors mentioned including the characteristics of foreign languages that are different from the learner's mother tongue has an important role in this matter. English speakers, for example, they write from left to right. Meanwhile, Arabic writing emphasizes the writer to write the letter starting from right to left. Likewise, it is very far differences in the form of letters between English and Arabic. For speakers of English, they must get applied to associate the new letters with the sounds of the letters. Besides in the problem of Arabic writing is different because some sounds are spoken but not written and also letters that are written but not spoken [6]. As a result, it signifies easy to be known that in learning foreign language nobody can acquire any language without doing some mistakes [7]. By making mistake is indicated that the students experience what they have done and they know the next step to be better in learning.

Besides, the problems of language learning can be interpreted into several factors that influence the ability and willingness of students to learn their second language. According to Dimyati and Mudjiono [6], these factors are categorized into some such as (1) the low motivation of students in partaking of learning, motivation to learn is the mental strength that strengthens the learning process, (2) lack of concentration on learning, this concentration signifies the ability to focus on learning, (3) lack of feeling student confidence, especially when they are learning the ability to speak in a second language context, this confidence is the stage of determining the "demonstration" of self that is recognized by the teacher and fellow students, (4) the problem comes from the teacher's side, refers to the teacher who does not foster a sense of professionalism which results in a bad outcome on students, the teacher as the student coach in learning so the teacher must sharpen on the student's personality in learning revival, (5) learning facilities and infrastructure inadequate, this holds a tool that helps the language learning process or it can be said that the complete learning infrastructure facilities that are provided must be well condition to support a good learning circumstance.

To ensure the gap, this research shows some related previous studies that are associated with the present research regarding the problem of learning a foreign language. First, Ozdemir [14] found that in learning Turkish as a foreign language, male students were pointed to get more problems in listening and writing while females got more problems in reading and speaking class. Second, Metboki [15] revealed that the problems in a professional teacher were indicated student teachers were still lacking to grounded concepts especially in case of what and how to develop ELT materials that fit students' needs. Third, Hidayati [16] stated that the problem in teaching writing for ELT class was from internal and external factors, the internal factors are classified as linguistic competence, native language interference, reading habit and motivation of the learners, while external factors were a class condition, teaching media for writing, and time management.

\subsection{Objective of Research}

From those explanations above, this paper aims to be more specific to describe the usual problems faced by non-native speaker students in Indonesia particularly in the context of "four language skills" and the language strategies used to overcome those problems in each language skill.

\subsection{Significance}

The significance of this research is addressed to the English and Arabic teacher who teaches Indonesian students. The findings of this research will be further consideration of teacher preparation before beginning the class also for their evaluation while facing the difficulties in teaching a foreign language.

\section{Materials and Methods}

This study used the library research method to obtain data answering the research question. The library research method holds as a method of data collection by reviewing several library works that are relevant and related based 
on existing problems [17].

According to this design, the data sources were taken selectively from the relevant literature such as Journal, Article, Research report and Book ab. The relevant literature was considered with the theme of this study, such as the problems commonly emerged in facing and learning Arabic and English, the article that is discussed about the strategy usually used to overcome the problems in learning a foreign language, and so on.

While after collecting the data needed, then the data were analyzed through two ways of thinking such as inductive and deductive. Inductive analysis was a way of thinking to draw conclusions starting from specific facts to general conclusions, while deductive analysis was a way of thinking to draw conclusions starting from general statements to specific questions using reasoning.

\section{Results and Discussion}

\subsection{Problems}

\subsubsection{Listening Skill}

Problems which were occurred on students while learning to listen to the second language were very complex and various. They did not just listen to it though they must understand the context of the theme delivered by the speaker or the sound media. According to Bingol et al. [18], there are four problems faced by students in listening class among others;

\section{a) The quality of recording equipment}

The teachers use recording equipment that does not have any good quality. The quality of the sound system can influence students' listening comprehension.

\section{b) Different culture}

Students belong to recognize language culture that has an important impact on their understanding of learning. If this task capability involves different cultural lessons entirely then what will occur is that students will face critical problems in understanding.

\section{c) Accent}

Many different accents can lead to a decreased understanding of listening skills. According to Goh [19], $66 \%$ of students mentioned that the accent of the speaker is one of the most important factors that influence a listening understanding. By not recognizing the accents, it will be assumed to be a serious problem and vice versa. Even without knowing the accent used by the speaker, it can disrupt the learning process itself.

\section{d) Unfamiliar vocabulary}

When the listening process is going on, it will be easier if students recognize the diction used by the speaker. Conversely, if students find many words that have more than one meaning and if the words are not used under the context of student life, it will confuse understanding [20].

Students who learn foreign languages at the beginning of learning generally encounter major problems in their ability to listen and understand them. They think that the reader or speaker is too fast in reading or speaking. This is because the sentences are close to each other, where they are less accustomed to hearing the words in a continuous sentence. Besides, this can also be caused by the fact that they first translated into their mother tongue to understand the meaning. Therefore, the concentration is divided and stacked because of the process of translation and understanding. But by doing listening exercises, students will be accustomed to distinguishing words in a sentence with the usual tempo of pronunciation. The language will move from a sense to a sense when the meaning has been connected with a certain position or with the sound of the pronunciation without the translation process [21].

Then it should be when the teacher reads a theme or a story, he also pays attention to the students' linguistic abilities, speed in distinguishing words, ability to concentrate, and ability to follow audio until understanding it. The teacher should also give a story to students that inherent toward their souls from what they heard and discussed [21].

\subsubsection{Speaking Skill}

Speaking represented as language skill that was pointed on the organ of humans called a mouth. According to Nakhalah [22] states that speaking indicates the process of conveying language through mouth. To speak, we created the sound using organs such as the throat, tongue, teeth, and lips. This skill was not an easy thing alike something that was mostly avoided for certain parties, because actually, the students had a feeling of less confidence to directly speak in public by using foreign languages.

These statements were supported by Celce-Murcia and Olshtain [23] that speaking skill can be considered as the most difficult ability in producing sound with vocabulary, proper use of grammar, and socio-cultural abilities [24]. At least there were 4 problems faced by students in developing a speaking skill. According to Nakhalah [22] mentions it among others;

\section{a) Fear doing mistakes}

A student acts afraid to make a mistake such as worry if his friends will laugh at him later and finally receive a negative judgment if they make a mistake in speaking English. According to Anandari [25], most of the students agree that their increased level of fear and anxiety due to they realized that they did not master in an aspect of content well, although they have written the speeches by themselves.

b) Shy 
This feeling of shy is related to performance in public especially in front of the class. Students will feel more uncomfortable until at last their minds directly out of focus or blank or can even make them forget what to say.

\section{c) Anxiety}

This concern can influence the performance of students. In this case, it influences the quality of producing sound and becomes not fluent than before or original. The indication of the anxiety occurrence is due to the student's feelings in terms of discomfort in his environment. According to Prastiyo, et al. [26] anxiety describes as one of the psychological conditions that commonly emerged in the teaching and learning process while students especially are uncertain toward what they are facing to learn.

\section{d) Less motivation}

The existence of motivation is quite important as a key consideration in determining communication on student preparation. In fact, according to Zua [27], adds that motivation can increase students' interest in learning which results in their achievement scores are improved. So if no motivation inside the learning process, speaking is very possible to be a burden for students because there is no interest in this language skill [28]. The sense of motivation is very significant implied in the learning process, due it is easily motivated students' learning and conversely less motivation will easily weaken the spirit of learning until the students will be frustrated and bored in participating learning class [29].

When someone learned Arabic, they ordered to encounter some problems related to articulation. This is caused by several factors as follows [30]:

- $\quad$ Students experience problems when speaking Arabic sounds that do not exist in their mother tongue

- Students usually hear some Arabic language sounds and speculate that the sound of the language is similar to the sound of their mother tongue, although they realize that the sound is different.

- Students usually experience problems when they listen to something and say it based on what they hear. Incorrect hearing, in this case, causes incorrect pronunciation.

\subsubsection{Reading Skill}

The process of reading was similar to the process of obtaining the contents written in the text or so on. Reading described the process of seeing and understanding the contents of what was written by orally or in heart and spelling or reciting what is written [2]. This skill aims to gain interaction between the reader and the text to be read [29]. In terms of the reading process what is belonged to be needed was an understanding of the meaning of words, which had written was ably interpreting the intent of the author. According to Rivers cited in Qarqez and Rasyid [29], reading is the most important activity in language classes, not only as a source of information and fun activities but also as a means of combining and expanding language insight.

Regarding the word, "understanding" was not something easy during reading a text. According to Nezami [30], the problem of reading arises through the frequency of students facing spelling and pronunciation of words broadly. Besides that, there was statement related with this case from another study. Elwér [31] reveals that a lack of interest read academic texts both containing the first and second languages. Clearly, the problems faced by students in developing the skill of reading are; (1) ambiguous words, (2) foreign vocabulary, (3) limited time to understand the text.

Learning Arabic sometimes encounters some problems in reading. Among these problems are [32]:

Additional letters. In some Arabic texts, there are several letters that are written but not pronounced, such as the alif letter in the word (ذهبوا), alif in the word (jاهدا), wawu in the word. (عروg. These letters cause problems for some students.

The letters that have changed. Some letters are not read as written. However, the letter changes into another sound according to the rules. Like lam, which is before syamsiyyah letter, due to these letters must be replaced at the letter sound afterward. Then the sound goes into the letter after it sounds like the word ash-syamsu. Some students say this word by speaking lam without changing it. This is contrary to the application of the right rules.

Unclear sounds. Most students face problems in pronouncing some sounds of Arabic, especially the sounds of thibaqiyyah ( and bold letters such as (ظ) ص ض when students read hard and will not appear when they read slowly.

Ibrahim [33] states that the problem in reading for students is caused by two things, namely:

- Physical health which consists of particular kinds, namely general health, vision, and hearing

- Preparation in reading some students cannot prepare mentally when they want to review a reading. Among these preparations are intelligence, alertness, and the ability to focus the mind.

\subsubsection{Writing Skill}

The skill to write defined as a process of expressing ideas from thoughts into written form. According to Nuha, [9] writing skill or al-kitabah is the ability to describe or express the contents of the mind, starting from the simplest aspects, such as writing words, to complex aspects of writing. Richard and Renandya [34] state that there is no doubt that writing is a very difficult ability for students, this difficulty occurs because in writing not only be able to process ideas but make the writing to be 
readable and easily understood by the reader.

Writing problems mentioned above were usual explanation however what was said to be difficult here was about the content of writing which contained several features inside. Husna et al. [35] states that in writing by using a foreign language, students have difficulties in terms of knowledge of content, vocabulary, paragraph organization, and others. These was added by Utami [36] who examined the writing of students using English that in addition to what was revealed by Husna et al. [35] there were other aspects such as the use of appropriate sentence structures, giving punctuation, spelling, formations or writing because these aspects made students are confused and even have difficulty in learning of writing skill about second language [37].

Therefore, there must be a strategy to handle it, so that students were easier to go forward for creating good and correct writing according to the rules that applied.

When the teacher reviews free essay done by the students, he will find some things that are not easy based on the following description [32]:

a) Several errors in writing.

b) Several linguistic elements that require correction and evaluation. This includes the structure of sentences, paragraphs, ideas, blessings, nahwu, imla', $k h o t h$, cohesiveness, which require teacher guidance.

c) Limited teacher time

\subsection{Learning Strategy}

\subsubsection{Listening Skill}

Some ways can do at listening to class. Among them a teacher should do;

a) Providing and preparing different input as learning media for instance; the use of interesting radio news media, videos, announcements, daily conversations, and interviews which the theme that will be taken sources from students' needs.

b) The teacher becomes a facilitator and someone who enthusiast in correcting any accent which is confused by the students. So that the students more understand and know well on what is correct and false catch by their ears.

c) Giving motivation in form of "feedback" on students' work after they finished listening session.

d) The teacher should invite the students to practice independently in each day, such as doing activity such as listen to music related to the second language either Arabic or English, listening to news from either radio or TV, if there is an opportunity student may ask to talk with foreigners or "native speaker" [32].

\subsubsection{Speaking Skill}

In the case of speaking skills learning, the most often arises was a lack of motivation that made students often feel worried, embarrassed, and afraid to make a mistake which eventually they did not try to speak at all. Therefore, the right thing to reduce or even eliminate these feelings in students was a teacher should;

a) Designing a class with pleasant states can be through play. Learning by playing can create an exciting atmosphere and free up full and unobstructed intelligence can give many advantages [37]. One example is the method of playing "guess what" or guessing between two people.

b) Creating a friendly class and an open environment which will make the student feel not worried about making mistakes. Chinmony [38] proposes that in terms of helping students to emerge their confidence is by convincing students directly and say "don't be afraid to fail or be successful" [22].

\subsubsection{Reading Skill}

The strategies used in improving reading skills and to reduce the problems within reading process can be done by several learning strategies. One of them is by doing the method of "al-Muwasa'ah". This reading model is used usually for understanding the long text. Students listen to text outside the classroom according to the teacher's advice. Then they discuss the main idea of the text in the classroom to empower their understanding. The unique of this method is that the text what students read is an initiative from students' own. It can be said that students are given the freedom to choose texts that they like or are interesting in [9].

\subsubsection{Writing Skill}

To sharpen students' writing skills and minimize boredom in writing, a teacher must change his strategies or teaching methods. One of these methods is to compose or al-insya'. Writing is a category of writing that is oriented towards the expression of the main thoughts in the form of ideas, messages, feelings, and others into written language [9]. This method can be done with several stages, among others;

a) Looking for topics that are under the level language of students with the scope of their daily life

b) Determining goals; why does the author compose the writing

c) Determine for whom the essay is intended

d) Make an outline plan

e) Realizing essays on paper. In this case, starting from a crude or raw concept, then revised and edited, neatly written on paper [39].

Thua'imah reveals that in writing class should involve the time for writing with a free theme. The teacher should accept all the students' thoughts either in all mufrodat, tarkib and ideas. Teacher acts as a corrector of student mistakes. This is undoubtedly more significant than requiring them to memorize a set of tarkibs as well as language rules [13].

The comparison between two research questions in this 
paper (1) the problems in learning language skills faced by non-native students and (2) the strategies used to overcome the existing problems showed that both have been completing each other. For instance, the problem emerged in speaking skills (shy to speak, fear of making, anxiety, and motivation) can be overcome by creating a friendly class and an open environment in form of a game, role play, or other fun activities. By having that, this finding then can reduce foreign language problems and challenges. As a result, the students are more comfortable to learn English and Arabic as a foreign language.

\section{Conclusions}

To sum up, the problems in learning foreign languages require more attention from the students. In each skills (listen, read, speak and write) has its variety and level of difficulty. This makes challenge for students to receive foreign language lessons in the classroom. Starting from technical problems to the motivations both students and instructors. Therefore, a strategy must always be provided to overcome or at least reduce the learning obstacles experienced by students to develop patterns of language skills.

By understanding the existing problems in this study, the teacher who either teaches Arabic or English must be more aware to select the way of their teaching to the students. Especially the language skill, each skill has its challenges and difficulties for students, consequently the teacher is very demanded to provide a suitable teaching strategy to overcome the existing problems in a foreign language class.

\section{REFERENCES}

[1] Sokip, Akhyak, and M. Hidayat, "Children Emotional Parenting and Islam Perspective," United Arab Emirates: Saudi Journal of Humanities and Social Sciences, vol. 4, no. 3, pp. 180-188, 2019.

[2] Izzan, The Methods of Arabic (revised edition). Bandung, Indonesia: Humaniora, 2009

[3] Al-khresheh, Mohammad. "A review study of contrastive analysis theory." Journal of Advances in Humanities and Social Sciences, 2, 6, (2016B): 330-338.

[4] Al-khresheh, Mohammad. "A review study of error analysis theory." International Journal of Humanities and Social Science Research, 2, (2016A); 49-59.

[5] Al-khresheh, Mohammad. "A review study of interlanguage theory." International Journal of Applied Linguistics \& English Literature, 4, 3, (2015):124 - 131.

[6] Al-khresheh, Mohammad. "An investigation of interlingual interference in the use of 'and' as a syntactic coordinating structure by Jordanian EFL learners." European Journal of

\section{Social Sciences, 18, 3, (2011): 426-433.}

[7] Al-khresheh, Mohammad. "Interlingual interference in the English language word order structure of Jordanian EFL learners." European Journal of Social Sciences, 16, 1, (2010): 106-113.

[8] Al-khresheh, Mohammad. The Misuse of Word Order in the Writing of Jordanian EFL Learners. Unpublished doctoral dissertation, University of Malaya, Kuala Lumpur, Malaysia. (2013).

[9] U. Nuha, The Most Effective Strategies used to Learn Arabic. Jogjakarta, Indonesia, Diva Press, 2012.

[10] Syukir, The Basics Strategies in Islamic Missionary. Surabaya, Indonesia: Al-ikhlas, 1983

[11] Dimyati, and Mudjiono. Study and Learning. Jakarta, Indonesia: Rineka Cipta, 2010.

[12] Syahputra, "Learning Strategies used for English as Foreign Language in Improving Students' Language Skills," Kutubkhanah, vol. 17, no. 1, pp. 127-145, 2015.

[13] R. A. Thu'aimah, The Handbook of Teaching Arabic for Arabs through Other Language Used. Makkah, Saudi Arabia: Jami'ah Ummul Qura', 1989.

[14] C. Ozdemir, "Causes of Problems Students Face While Learning Turkish as a Foreign Language: The Case of Kazakhstan," The European Educational Researcher, vol. 1, no. 1, pp. 17-33, 2018.

[15] Y. Metboki, "Problems Hindering Student Teachers' ELT Materials Development: A Study in Internship Program in Eastern Indonesia," English Review: Journal of English Education, vol. 7, no. 1, pp. 93-104, 2018.

[16] K. H. Hidayati, "Teaching Writing to EFL Learners: An Investigation of Challenges Confronted by Indonesian Teachers," Langkawi: Journal of The Association for Arabic and English, vol. 4, no. 1, pp. 21-31, 2018.

[17] S. Hadi, "Research methods," Unpublished thesis. Psychology Fakulty, Universitas Gajah Mada, Yogyakarta, Indonesia, 1981

[18] M. A. Bingol, B. Celik, N. Yildiz, and C. T. Mart, "Listening Comprehension Difficulties Encountered by Students in Second Language Learning Class," Journal of Educational \& Instructional Studies in the World, vol. 4, no. 4, pp. 1-6, 2014.

[19] C. M. Goh, "Learning to Listen," REACT, vol. 1999, no. 2, pp. $44-53,1999$.

[20] P. Gilakjani, and N. B. Sabouri, "Learners' Listening Comprehension Difficulties in English Language Learning: A Literature Review," English Language Teaching, vol. 9, no. 6 , pp. $123-133,2016$

[21] Hadidy, The Problems in Teaching Arabic for Non-Native of Arabic. Khairo, Dar al-Kaatib al-'Arab, 1998

[22] M. M. Al Nakhalah, "Problems and Difficulties of Speaking that Encounter English Language Students at Al Quds Open University," International Journal of Humanities and Social Science Invention, vol. 5, no. 12, pp. 96-101, 2016

[23] E. Olshtain, and M. Celce-Murcia, "36 Discourse Analysis 
and Language Teaching," In The handbook of Discourse Analysis, Oxford, UK: Blackwell Publisher, pp. 707-724, 2001.

[24] A. Al-Roud, "Problems of English Speaking Skill that University Students Encounter from Their Perspectives," Journal of Education, Society and Behavioural Science, vol. 18 , no. 3 , pp. 1-9, 2016.

[25] L. Anandari, "Indonesian EFL Students' Anxiety in Speech Production: Possible Cases and Remedy," State University of Malang: TEFLIN Journal, vol. 26, no. 1, pp. 1-16, 2015.

[26] J. T. Prastiyo, Sokip, A. Tanzeh, Soim, and Akhyak, "Investigating EFL Students' Psychological Anxiety in Reading Performance," Pakistan: Sumerianz Journal of Social Science, vol. 2, no. 8, pp. 148-154, 2019.

[27] L. Zua, "Exploring the affective factors influencing teaching of spoken English," The Asian EFL Journal Quarterly, 2008.

[28] Sokip and Akhyak, "Arabic Learning Strategy in Islamic State University of Malang (Case Study about Strategy in improving learning motivation at UIN Malang)," India: International Academy of Science, Engineering and Technology, vol. 8, no. 2, pp. 63-78, 2019

[29] M. Qarqez, and R. A. Rashid, "Reading Comprehension Difficulties Among EFL Learners: The Case of First and Second Year Students at Yarmouk University in Jordan," Jordan: Arab World English Journal (AWEJ), vol. 8, no. 3, pp. 422-423, 2017

[30] S. R. A. Nezami, (2012). "A Critical Study of Comprehension Strategies and General Problems in Reading Skill Faced by Arab EFL Learners with Special Reference to Najran University in Saudi Arabia," International Journal of Social Sciences \& Education, vol. 2 , no. 3 , pp. 306, 315, 2012

[31] Elwér, Early predictors of reading comprehension difficulties," Doctoral dissertation. Linköping University Electronic Press, Linköping, Sweden, 2014.

[32] Khuly, Muhammad Aly. Asaaliib Tadris al-Lughat al-'Arabiyat. Riyath: al-Mamlakah al-'Arabiyah as-Sa'ud, 1982

[33] A. Ibrahim, The Teaching Guidance Book for Arabic Teacher. Khairo, Dar al-Ma'arif, 1968.

[34] J. C. Richard, and W. A. Renandya, Methodology in Language Teaching an Anthology of Current Practice. Cambridge, UK, Cambridge University Press, 2002.

[35] L. Husna, Zainil, and Y. Rozimela, "An Analysis of Students' Writing Skill in Descriptive Text at Grade XI IPA 1 of MAN 2 Padang," Journal English Language Teaching, vol. 1, no. 2, pp. 1-16, 2013.

[36] T. A. A. Utami, "Improving the Ability in Writing Descriptive Text Through Brainstorming Technique for Grade VIII Students at SMPN 1 Piyungan," Unpublished thesis. Universitas Negeri Yogyakarta, Yogyakarta, Indonesia, 2014.

[37] F. R. Mujib, and Nailur, The Strategy of Learning Arabic through Educative Plays. Jogjakarta, Indonesia, Diva Press, 2013.
[38] S. Chinmoy, How to Overcome Shyness [Online], 2007. Available: https://bit.ly/2Yp234I

[39] S. U. N. Subyakto, Psycholinguistics an Introduction. Jakarta, Indonesia: PT Gramedia Pustaka Utama, 1992 